\title{
The Value of Combined Measuring of the Cerebrospinal Fluid Lactate and Serum Procalcitonin in Diagnosis of Acute Bacterial Meningitis
}

\author{
Hosam M Dawod ${ }^{1}$, Ahmed S Awadallah ${ }^{2}$, Seham Mahrous ${ }^{3}$, Ahmed \\ Alwassief $^{4}$, Sameh M Abdel Monem ${ }^{1}$ \\ ${ }^{1}$ Department of Tropical Medicine Department, Faculty of Medicine, Zagazig \\ University, Egypt. \\ ${ }^{2}$ Medicine Department, Zagazig Fever Hospital, Egypt. \\ ${ }^{3}$ Department of Clinical Pathology, Faculty of Medicine, Zagazig University, Egypt. \\ ${ }^{4}$ Department of Internal Medicine, Al Azhar University forBoys, Cairo Campus, Egypt.
}

Corresponding Author Hosam Mohamed

Dawod

Mobile:

0096871583895

$002 \quad 01113008201$

E mail:

hosamgastro@yahoo.c om

Key words:

Bacterial meningitis, Procalcitonin, Lactate, CSF
Backgroundand study aim:The differential diagnosis between bacterial meningitis and aseptic meningitis is a critical clinical issue and searching for reliable and valid markers is required. This work aimed to assess the role of the combined measuring of CSF lactate and serum procalcitonin in the diagnosis of acute bacterial meningitis.

Patients and Method:A cross-sectional study including 42 meningitis patients was conducted at Zagazig Fever Hospital and Zagazig University Hospitals in the period from November 2018 to June 2019, Patients were divided according to their final diagnosis into two groups; group I included 13 patients with bacterial meningitis ( positive CSF bacterial culture and/or Gram stain ), group II included 29 patients with aseptic meningitis (negative CSF bacterial culture and Gram stain), The data collection sheet included clinical

\section{INTRODUCTION}

Bacterial meningitis is an inflammation of the meninges due to bacterial infection and represents one of the endemic diseases in Egypt $[1,2]$. Aseptic meningitis is an inflammation of meninges without evidence of bacterial infection on bacterial cultures and Gram staining. It is usually accompanied by a mononuclear pleocytosis [3].The commonest cause of bacterial meningitis is Neisseria meningitidis, Haemophilus influenzae type $b$, Streptococcus pneumoniae [4], while the common cause of aseptic meningitis is viral meningitis [5]. Acute bacterial meningitis requires early diagnosis and immediate assessments, lumbar puncture with CSF analysis, CSF lactate level testing, and Serum procalcitonin level testing.

Results: One hundred five of house officer participated Serum procalcitonin and CSF lactate levels were significantly higher in the bacterial meningitis group $(1.16 \pm 1.24,7.5 \pm 6.6$, respectively) than patients with aseptic meningitis $(0.059 \pm$ $0.04, \quad 3.98 \pm 2.1$, respectively). The measuring of both serum procalcitonin and CSF lactate levels had got a higher sensitivity, specificity, and accuracy (96.6\%, $76.9 \%, 90.9 \%$ respectively) for the diagnosis of bacterial meningitis more than measuring either of them only.

Conclusion: The combined measuring of both serum procalcitonin and CSF lactate levels is highly accurate in the diagnosis of bacterial meningitis cases and helps to differentiate bacterial meningitis from aseptic meningitis.

intravenous administration of antibiotics, whereas aseptic meningitis is usually self-limiting so, the delay of accurate treatment increases the adverse outcomes. Furthermore, signs and symptoms are often non-specific in the early phases of meningitis, and it is not always possible to make a diagnosis based on the routine examination of CSF [6]. Positive CSF bacterial culture and Gram staining are considered the gold standard in the diagnosis of bacterial meningitis. However, they have poor sensitivity and the bacterial culture is timeconsuming [7]. 
The serum and CSF markers currently used in bacterial meningitis diagnosis, as C-reactive protein, are also characterized by poor sensitivity and specificity. Therefore, searching for reliable and valid markers with more sensitivity and specificity for bacterial meningitis is required [8]. The level of CSF lactate was considered a useful marker for the differentiation of bacterial meningitis from viral meningitis [9]. Procalcitonin (PCT) is a 116-amino-acid protein that is formed by the parafollicular cells of the thyroid, the neuroendocrine cells, and the leukocytes. The level of serum PCT increases markedly in bacterial infections in response to various proinflammatory cytokines. The raised level of PCT may be used as a good marker for the diagnosis of bacterial meningitis $[\mathbf{1 0 , 1 1 ]}$. This work aimed to assess the role of the combined measuring of CSF lactate and serum procalcitonin in the diagnosis of acute bacterial meningitis.

\section{PATIENTS AND METHODS}

A cross-sectional study including 42 meningitis patients was conducted at Zagazig Fever Hospital and Zagazig University Hospitals in the period from November 2018 to June 2019. Inclusion Criteria; Patients with clinical picture suggestive of meningitis (headache, fever, projectile vomiting, nuchal rigidity, Kernig's sign, and Brudzinski's signs) and CSF analysis suggestive of meningitis. Exclusion Criteria; Patients with either of the following; a disease that causes an increase in CSF lactate such as epilepsy, intracranial hemorrhage and malignancy, another site of infection besides meningitis, brain tumor, other causes of impaired conscious levels or neurological insults, antibiotic treatment before admission and tuberculosis or fungal meningitis.

Patients were divided according to their final diagnosis into two groups; group I included 13 patients with bacterial meningitis (positive CSF bacterial culture and/or Gram stain), group II included 29 patients with aseptic meningitis (negative CSF bacterial culture and Gram stain) $[12,13]$. All patients were exposed to:

thorough clinical assessment; including personal data, presenting complaints, general symptoms, neurological symptoms, general examination, and neurological examination.
- $\quad$ L

aboratory investigations; Complete blood count (CBC), Erythrocyte sedimentation rate (ESR), C reactive protein (CRP), random blood sugar.

-

umbar Puncture (LP) and CSF analysis; The patient assumed the lateral recumbent position. After palpating the landmarks, preparing the skin was done with disinfectant and local anesthesia, the needle was inserted in the inter-space between L3 and L4 or L4 and L5, in the midline and around 15 degrees cephalic [14]. CSF analysis;1-Physical (aspect and pressure), 2- Cell count: total and differential leukocyte count, 3- Chemical glucose and protein content, 4Bacteriological analysis culture, and Gram stain. Patients with clinical risk factors for raised intracerebral pressure with subsequent risk for cerebral herniation had a CT scan of the head before LP [15].

-

\section{C}

SF lactate level testing, by Cobas 6000 (c501, Roche, Japan), Test principle; colorimetric assay. Normal level $1.1-2.4 \mathrm{mmol} / \mathrm{L}$ [16].

erum PCT level testing, by Cobas (e 601, Roche, Japan), Test principle; electrochemiluminescence immunoassay. The normal level is $<0.05 \mathrm{ng} / \mathrm{mL}$ [11].

$\bullet$

mpiric treatment was initiated directly after CSF sampling or when it was deferred with the following regimen: Vancomycin plus a third-generation cephalosporin (ceftriaxone or cefotaxime) plus ampicillin (in adults $>50$ years of age or children $<3$ months) plus dexamethasone (starting before the first dose of antibiotics) [8].

\section{Statistical analysis}

All information was gathered and arranged by utilizing SPSS 22.0 for windows (SPSS Inc., Chicago, IL, USA) and Med Calc 13 for windows. Constant information is summarized as the mean \pm SD and middle (extend), and the A qualitative data is presented as a number (frequency). Mann-Whitney U test was applied to compare non-ordinarily dispersed data between the two groups. The Chi-square test or Fisher's precise test were used to analyze qualitative data. Receiver operating characteristic 
(ROC) curve analysis was used to identify optimal cut-off values. $\mathrm{p}<0.05$ was considered statistically significant.

\section{RESULTS}

This study included 42 meningitis cases (24 males and 18 females) with ages ranging from 6 months to 73 years. There was no statistically significant difference between the two groups for gender and age (Table 1). According to the results of CSF bacterial culture and Gram staining, the patients were divided into two groups; the bacterial meningitis group (I) included thirteen patients (31\%) who had a positive CSF bacterial culture and Gram stain results., and the aseptic meningitis group (II) included twenty-nine patients $(69 \%)$ who had a negative CSF bacterial culture and Gram stain results. The isolated bacteria included Neisseria meningitidis in 7 cases, Streptococcus Pneumoniae in 3 cases, Haemophilus influenzae in 2 cases, Escherichia coli in one case. Table 2, compared the clinical manifestations of the two groups and showed a significant increase in the incidence of Kernig's sign, Brudzinski's sign, and neck stiffness $(30.8 \%, \quad 30.8 \%, \quad 76.9 \%$ respectively) in the bacterial meningitis group when compared with the aseptic meningitis group $(6.9 \%, 6.9 \%, 13.8 \%$ respectively). The main presenting manifestation of bacterial meningitis in our study was fever $(100 \%)$, neck stiffness $(76.9 \%)$, headache $(61.5 \%)$, disturbed level of consciousness (61.5\%), convulsion
(53.8), vomiting (53.8\%), Brudzinski (30.8\%), and Kernig's (30.8\%).

Table 3 shows that the mean levels of blood total leukocyte count (TLC), ESR, and CRP in the bacterial meningitis group $(14.06 \pm 6.85,47.1 \pm$ $26.9,103.3 \pm 99$ respectively) were significantly more than the aseptic meningitis group ( $9.574 \pm$ $4.11,14.0 \pm 6.4,13.8 \pm 9.8$ respectively). The CSF analysis of the studied cases showed that the CSF TLC, polymorphonucleocyte (PMN), and protein levels $(7500,80 \pm 9.1,208.2 \pm 83.1$ respectively ) were significantly higher in bacterial meningitis group than aseptic meningitis group $(15,18 \pm 9.3,53.6 \pm 89.8$ respectively), whereas the CSF lymphocyte and glucose mean levels were significantly higher in the aseptic meningitis group $(81.9 \pm 9.3,73.6 \pm$ 22 respectively) than the bacterial meningitis group $(19.5 \pm 9.1,42.0 \pm 12.7$ respectively). Serum PCT and CSF lactate levels were significantly higher in the bacterial meningitis group (1.16 $\pm 1.24,7.5 \pm 6.6$, respectively) than patients with aseptic meningitis $(0.059 \pm 0.04$, $3.98 \pm 2.1$, respectively). Table 4 illustrates that the combined measuring of serum PCT and CSF lactate levels had a higher sensitivity, specificity, and accuracy $(96.6 \%, \quad 76.9 \%, \quad 90.9 \%$ respectively) for the diagnosis of bacterial meningitis than testing either of them alone. ROC analysis showed a significant high area under the curve (AUC) for the combined measuring of CSF lactate and serum PCT when compared with AUC for measuring either of them only (figure 1)..

Table (1): Comparison of demographic data between the two groups .

\begin{tabular}{|c|l|c|c|c|c|}
\hline \multicolumn{2}{|c|}{} & $\begin{array}{c}\text { Bacterial meningitis } \\
(\mathbf{n = 1 3})\end{array}$ & $\begin{array}{c}\text { Aseptic meningitis } \\
(\mathbf{n = 2 9})\end{array}$ & $\begin{array}{c}\text { Test of } \\
\text { significance }\end{array}$ & P-value \\
\hline \multirow{2}{*}{ Gender } & Male n (\%) & $\begin{array}{c}10(76.9 \%) \\
(23.1 \%)\end{array}$ & $\begin{array}{c}14(48.2 \%) \\
15(51.8 \%)\end{array}$ & $\dagger 3.01$ & 0.08 \\
& Female n (\%) & $1-60$ & $0.5-73$ & \multirow{2}{*}{$\dagger+0.35$} & 0.5 \\
\hline $\begin{array}{c}\text { Age } \\
\text { (years) }\end{array}$ & Range & Median & 22 & 15 & $\dagger$ \\
\hline
\end{tabular}

$\dagger$ Chi-square test. $\dagger \dagger$ Mann-Whitney U test. $\mathrm{P}=$ Level of significance 
Table (2): Clinical manifestation of the studied groups.

\begin{tabular}{|l|c|c|c|c|}
\hline & $\begin{array}{c}\text { Bacterial meningitis } \\
(\mathbf{n = 1 3})\end{array}$ & $\begin{array}{c}\text { Aseptic meningitis } \\
(\mathbf{n = 2 9 )}\end{array}$ & $\mathbf{X}^{\mathbf{2}}$ & P-value \\
\hline Fever & $13(100 \%)$ & $28(96.9 \%)$ & 0.17 & 0.67 \\
\hline Headache & $8(61.5 \%)$ & $11(37.9 \%)$ & 2.02 & 0.15 \\
\hline Neck stiffness & $10(76.9 \%)$ & $4(13.8 \%)$ & 13.38 & $0.001^{*}$ \\
\hline Kernig's sign & $4(30.8 \%)$ & $2(6.9 \%)$ & 4.18 & $0.04^{*}$ \\
\hline Brudzinski sign & $4(30.8 \%)$ & $2(6.9 \%)$ & 4.18 & $0.04^{*}$ \\
\hline Vomiting & $7(53.8 \%)$ & $16(55.2 \%)$ & 0.01 & 0.93 \\
\hline Convulsion & $7(53.8 \%)$ & $18(62.1 \%)$ & 0.25 & 0.61 \\
\hline $\begin{array}{l}\text { Disturbed level of } \\
\text { consciousness }\end{array}$ & $8(61.5 \%)$ & $14(48.3 \%)$ & 0.63 & 0.42 \\
\hline Irritability & $3(23.1 \%)$ & $3(10.3 \%)$ & 0.38 & 0.53 \\
\hline
\end{tabular}

All values are expressed as number (percentage). $* \mathrm{P}<0.05$ is significant. $\mathrm{X} 2=$ Chi-square test..

Table (3): Comparison of the Laboratory results between the two groups.

\begin{tabular}{|c|c|c|c|c|c|}
\hline & & $\begin{array}{c}\text { Bacterial meningitis } \\
(\mathrm{n}=13)\end{array}$ & $\begin{array}{c}\text { Aseptic meningitis } \\
(\mathrm{n}=29)\end{array}$ & t-test & P-value \\
\hline \multirow[t]{3}{*}{$\overline{\mathrm{CBC}}$} & $\operatorname{TLC}\left(\times 10^{3} / \mathrm{mm}^{3}\right)$ & $\begin{array}{l}14.06 \pm 6.85 \\
(4.4-28.22)\end{array}$ & $\begin{array}{c}9.574 \pm 4.11 \\
(3.9-18.80 \\
\end{array}$ & 2.64 & $0.01 *$ \\
\hline & Hemoglobin $(\mathrm{g} / \mathrm{dl})$ & $\begin{array}{c}10.5 \pm 1.2 \\
(9.0-12.7)\end{array}$ & $\begin{array}{l}10.9 \pm 1.51 \\
(7.8-13.3) \\
\end{array}$ & 1.01 & 0.32 \\
\hline & Platelet $\left(\times 10^{3} / \mathrm{mm}^{3}\right)$ & $\begin{array}{l}271.1 \pm 127 \\
(123-505)\end{array}$ & $\begin{array}{c}263.3 \pm 98 \\
(88-453)\end{array}$ & 0.21 & 0.83 \\
\hline \multicolumn{2}{|c|}{ Serum glucose } & $\begin{array}{c}156.2 \pm 60.4 \\
(90-310)\end{array}$ & $\begin{array}{c}158.4 \pm 40.9 \\
(90-290)\end{array}$ & 0.139 & 0.889 \\
\hline \multicolumn{2}{|l|}{ ESR } & $\begin{array}{c}47.1 \pm 26.9 \\
(14-96) \\
\end{array}$ & $\begin{array}{c}14.0 \pm 6.4 \\
(6-23) \\
\end{array}$ & 6.3 & $0.001 *$ \\
\hline \multicolumn{2}{|c|}{$\begin{array}{l}\text { CRP } \\
\quad \text { Mean } \pm \text { SD }\end{array}$} & $\begin{array}{c}103.3 \pm 99 \\
72(4-300)\end{array}$ & $\begin{array}{l}13.8 \pm 9.8 \\
12(4-36)\end{array}$ & 13.1 & $\dagger 0.001 *$ \\
\hline \multirow{6}{*}{\begin{tabular}{|l} 
CSF \\
Findings
\end{tabular}} & TLC (median, range) & $7500(200-47900)$ & $15(3-70)$ & 25.0 & $\dagger 0.001^{*}$ \\
\hline & PMN (\%) & $\begin{array}{c}80 \pm 9.1 \\
(60-92) \\
\end{array}$ & $\begin{array}{c}18 \pm 9.3 \\
(10-40) \\
\end{array}$ & 20.0 & $0.001 *$ \\
\hline & Lymphocyte (\%) & $\begin{array}{l}19.5 \pm 9.1 \\
(8-40)\end{array}$ & $\begin{array}{l}81.9 \pm 9.3 \\
(60-90)\end{array}$ & 20.1 & $0.001 *$ \\
\hline & Glucose & $\begin{array}{c}42.0 \pm 12.7 \\
(24-63) \\
\end{array}$ & $\begin{array}{l}73.6 \pm 22 \\
(40-118) \\
\end{array}$ & 5.03 & $0.001^{*}$ \\
\hline & Protein & $\begin{array}{l}208.2 \pm 83.1 \\
(110-408)\end{array}$ & $\begin{array}{c}53.6 \pm 89.8 \\
(10-309)\end{array}$ & 5.2 & $0.001 *$ \\
\hline & CSF lactate (mmol/L) & $\begin{array}{c}7.5 \pm 6.6 \\
(1.7-22.7) \\
\end{array}$ & $\begin{array}{l}3.98 \pm 2.1 \\
(1.7-8.3)\end{array}$ & 2.26 & $0.012 *$ \\
\hline \multicolumn{2}{|c|}{$\begin{array}{l}\text { Serum procalcitonin (PCT) } \\
(\mathrm{ng} / \mathrm{mL})\end{array}$} & $\begin{array}{c}1.16 \pm 1.24 \\
(0.127-4.22)\end{array}$ & $\begin{array}{l}0.059 \pm 0.04 \\
(0.02-0.17)\end{array}$ & 4.6 & $>0.001 *$ \\
\hline
\end{tabular}

All values are expressed as mean \pm standard deviation (SD) and range; unless otherwise stated. PMN (polymorphonucleocyte). Reference ranges for CSF constituents: TLC (total leukocyte count) reference (0-3 cells/ul), Glucose reference $(50-80 \mathrm{mg} / \mathrm{dl})$. Protein reference $(15-45 \mathrm{mg} / \mathrm{dl})[17] .{ }^{*} \mathrm{P}<0.05$ is significant. $\dagger \mathrm{P}$ value of Mann-Whitney u test. 
Table (4): Validity of serum PCT and CSF lactate in the diagnosis of bacterial meningitis.

\begin{tabular}{|l|c|c|c|c|c|}
\hline & Sensitivity & Specificity & PPV & NPV & Accuracy \\
\hline Serum procalcitonin (PCT) & $93.1 \%$ & $69.2 \%$ & $87.1 \%$ & $81.0 \%$ & $85.7 \%$ \\
\hline CSF lactate & $75.9 \%$ & $46.2 \%$ & $75.9 \%$ & $46.2 \%$ & $66.7 \%$ \\
\hline $\begin{array}{l}\text { Combined measuring } \\
\text { (Serum PCT and CSF lactate) }\end{array}$ & $96.6 \%$ & $76.9 \%$ & $90.3 \%$ & $90.9 \%$ & $90.9 \%$ \\
\hline
\end{tabular}

PPV (Positive predictive value). NPV (Negative predictive value).

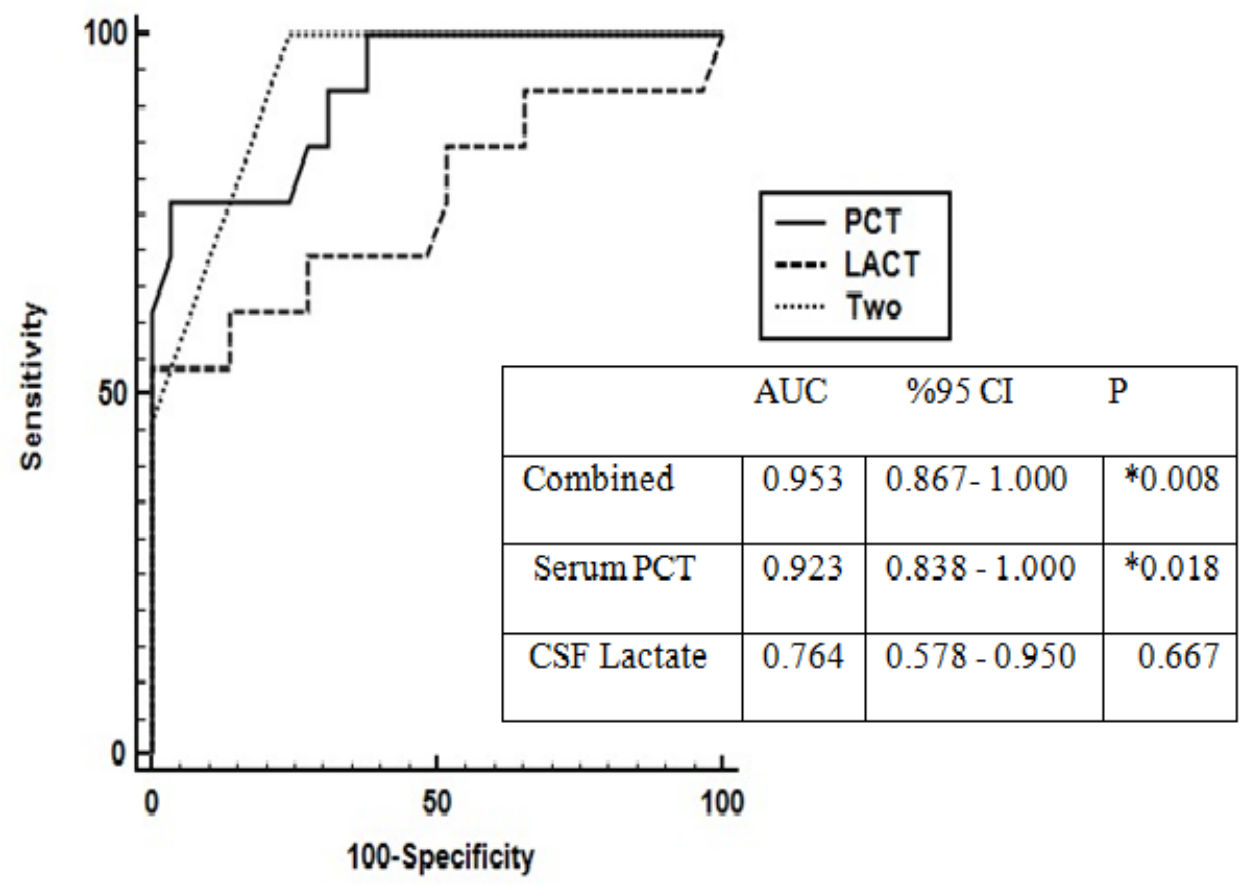

Fig. (1): ROC curve of CSF lactate, serum PCT, and combined measuring of the two tests.

(AUC ( Area under the curve), CI (Confidence interval), $* \mathrm{P}<0.05$ is significant)

\section{DISCUSSION}

Meningitis is a public health problem that requires an accurate and rapid diagnosis, which in turn affects the disease management and outcome [6]. The already used tools as CSF Gram stain, cultures, and chemical CSF examination, have limitations to diagnose and differentiate between bacterial and aseptic meningitis. [18]. Therefore, this study aimed to evaluate the role of combined testing of serum PCT, and CSF lactate in the diagnosis of bacterial meningitis.

Our study included $57.1 \%$ male and $42.9 \%$ female, with no significant difference for age and gender distribution between bacterial and aseptic meningitis groups, these results agreed with those of Abro et al. [19], Alkholi et al. [20]. The commonest presenting manifestation of bacterial meningitis was fever $(100 \%)$, followed by neck stiffness and headache, whereas Thomas et al., reported that headache (92\%) followed by fever
(71\%) were the main presenting symptoms for meningitis [21], this difference can be explained by selection bias as our patients were recruited from a fever hospital.

The patients with bacterial meningitis in this study had significantly higher blood TLC, ESR, and CRP levels than patients with aseptic meningitis. These results agreed with those of Makoo et al., who found a significant difference between acute bacterial meningitis and aseptic meningitis regarding TLC and ESR and CRP levels in favor of patients with bacterial meningitis [22]. This finding can be explained by the hematological reaction in response to bacterial infection [23]. The patients with bacterial meningitis also had significantly higher levels of CSF TLC, PMN, and protein than patients with aseptic meningitis, while they had significantly lower levels of CSF glucose and lymphocyte than patients with aseptic meningitis. Many studies reported similar findings [22,24]. 
The elevated CSF protein level is due to the disruption and increased permeability of the blood-brain barrier by the bacteria and the immune system reaction[25]. The hypoglycorrhachia (CSF glucose $<45 \mathrm{mg} / \mathrm{dl}$ ) in bacterial meningitis is due to the disruption of glucose diffusion and increased glucose consumption in response to bacterial infection [26].

CSF lactate level at a cut-off value $\geq 2.4 \mathrm{mmol} / 1$ showed a $66.7 \%$ diagnostic accuracy, $75.9 \%$ sensitivity, $46.2 \%$ specificity, $46.2 \%$ Negative predictive value (NPV), and $75.9 \%$ positive predictive value (PPV) which seemed to be inadequate for differentiating bacterial meningitis from aseptic meningitis. This result nearly agrees with Schwarz et al., who found that CSF lactate at cut-off value $\geq 2.1$ had a sensitivity of $94 \%$, but the specificity was low $(42 \%)$ and considered it a weak and unsatisfactory marker for differentiating bacterial and aseptic meningitis [27], on the other side, many studies reported high sensitivity, specificity, and NPV but at a higher cut off values $(3-3.5 \mathrm{mmmol} / \mathrm{l})$ and concluded that CSF lactate could help in the diagnosis of bacterial meningitis $[\mathbf{2 8 , 2 9 , 3 0 ]}$, this controversy makes the combination of biomarkers more favorable than single biomarker as recommended recently by Danish study, which found that combination of biomarkers increased the predictive value and recommended against using a single biomarker alone to establish or exclude the diagnosis [29].

Our study showed that serum PCT level at a cutoff value $\geq 0.075 \mathrm{ng} / \mathrm{dl}$ was a reliable biomarker in differentiating bacterial meningitis from aseptic meningitis (the diagnostic accuracy $85.7 \%$, sensitivity $93.1 \%$ specificity $69.2 \%$, NPV of $81.0 \%$, and PPV of $87.1 \%$ ). Different studies showed wide variations in the sensitivity, specificity, and cut-off values of serum PCT, this variation could be attributed to the diverse age range and nature of the study populations [20]. We statistically analyzed the combined testing of both the serum PCT and CSF lactate, to determine their diagnostic usefulness as a novel and clinically feasible diagnostic indicator of bacterial meningitis. The combined measuring of serum PCT and CSF lactate data demonstrated increased sensitivity (96.6\%), specificity (76.9\%), PPV (90.3\%), NPV (90.3\%), and accuracy $(90.9 \%)$, when compared with the measuring of either of them only. Although serum PCT showed relatively high accuracy
(85.7\%), the combined testing of serum PCT and CSF lactate demonstrated more accuracy (90.9\%) than serum PCT alone. this result indicates that combined measuring of both tests could be a useful diagnostic parameter for accurate differentiation of acute bacterial from aseptic meningitis.

\section{Limitations}

Small study population. Unavailability of Polymerase chain reaction test in Zagazig fever hospital. It can help in identifying the pathogen, particularly if negative CSF culture and could be a standard reference test for the validation of serum PCT and CSF lactate.

\section{CONCLUSION}

The combined measuring of both serum procalcitonin and CSF lactate levels is highly accurate in the diagnosis of bacterial meningitis cases and helps to differentiate bacterial meningitis from aseptic meningitis.

Recommendations: Measuring both CSF lactate and serum PCT in routine workup of suspected meningitis cases to help in the diagnosis of bacterial meningitis while awaiting the culture results. Multi-center studies with a large sample size to compare the combined testing of CSF lactate level and serum PCT with other noninvasive markers, and to assess its prognostic value.

Ethical considerations: A review board of the Tropical Medicine Department of Zagazig University approved the protocol in concordance with the Medical Association Code of Ethics (declaration of Helsinki). Written informed consent was taken from all participants.

Funding: None.

Conflicts of interest: No conflict of interest.

\section{REFERENCES}

1. Nudelman Y, Tunkel A. Bacterial Meningitis. Drugs 2009;69(18):2577-2596.

2. Fouad R, Khairy M, Fathalah W, Gad T, ElKholy B, Yosry A. Role of Clinical Presentations and Routine CSF Analysis in the Rapid Diagnosis of Acute Bacterial Meningitis in Cases of Negative Gram Stained Smears. Journal of Tropical Medicine 2014;2014:1-7. 
3. Logan S, MacMahon E. Viral meningitis. BMJ. 2008;336(7634):36-40.

4. Global, regional, and national age-sex specific all-cause and cause-specific mortality for 240 causes of death, 1990-2013: a systematic analysis for the Global Burden of Disease Study 2013. The Lancet. 2015;385(9963):117-171.

5. Ginsberg L. Difficult and recurrent meningitis. Journal of Neurology, Neurosurgery \& Psychiatry. 2004;75(90001):16i-21.

6. Van de Beek D, de Gans J, Tunkel A, Wijdicks E. Community-Acquired Bacterial Meningitis in Adults. New England Journal of Medicine. 2006;354(1):44-53.

7. $\mathrm{Wu} \mathrm{H}$, Cordeiro S, Harcourt B, Carvalho M, Azevedo J, Oliveira T et al. Accuracy of realtime PCR, Gram stain and culture for Streptococcus pneumoniae, Neisseria meningitidis and Haemophilus influenzae meningitis diagnosis. BMC Infectious Diseases. 2013;13(1).

8. Tunkel A, Hartman B, Kaplan S, Kaufman B, Roos K, Scheld W et al. Practice Guidelines for the Management of Bacterial Meningitis. Clinical Infectious Diseases. 2004;39(9):1267-1284.

9. Mekitarian Filho E, Horita S, Gilio A, Nigrovic L. Cerebrospinal fluid lactate level as a diagnostic biomarker for bacterial meningitis in children. International Journal of Emergency Medicine. 2014;7(1).

10. Meisner M. Update on Procalcitonin Measurements. Annals of Laboratory Medicine. 2014;34(4):263-273.

11. Velissaris D, Pintea M, Pantzaris N, Spatha E, Karamouzos V, Pierrakos C, et al. The Role of Procalcitonin in the Diagnosis of Meningitis: A Literature Review. Journal of Clinical Medicine. 2018;7(6):148.

12. Fenichel G. Clinical pediatric neurology, Paroxysmal Disorders. Philadelphia, PA: Saunders/Elsevier; 2009, 1-48.

13. Shukla B, Aguilera E, Salazar L, Wootton S, Kaewpoowat Q, Hasbun R. Aseptic meningitis in adults and children: Diagnostic and management challenges. Journal of Clinical Virology. 2017;94:110-114.

14. López T, Sánchez FJ, Garzón JC, Muriel C. Spinal anesthesia in pediatric patients. Minerva Anestesiol. $2012 ; 78(1): 78-87$.

15. Joffe A. Lumbar Puncture and Brain Herniation in Acute Bacterial Meningitis: A Review. Journal of Intensive Care Medicine. 2007;22(4):194-207.

16. NHS. NHS Choices. https://www.gloshospitals.nhs.uk/ourservices/services-we-offer/pathology/tests-andinvestigations/lactate-csf/.
17. Kaplan L, Pesce A. Clinical chemistry. 5th ed, St. Louis, Missouri: Mosby Elsevier; 2010, 904-928.

18. Leib S, Boscacci R, Gratzl O, Zimmerli W. Predictive Value of Cerebrospinal Fluid (CSF) Lactate Level Versus CSF/Blood Glucose Ratio for the Diagnosis of Bacterial Meningitis Following Neurosurgery. Clinical Infectious Diseases. 1999;29(1):69-74.

19. .Abro A, Abdou A, Ustadi A, Saleh A, Younis N, Doleh W. CSF lactate level: a useful diagnostic tool to differentiate acute bacterial and viral meningitis. J Pak Med Assoc. 2009;59(8):508511.

20. Abd El-Azim A, Sultan M, Alkholi U, Abd Almonem N. Serum procalcitonin in viral and bacterial meningitis. Journal of Global Infectious Diseases. 2011;3(1):14.

21. Thomas K, Hasbun R, Jekel J, Quagliarello V. The Diagnostic Accuracy of Kernig's Sign, Brudzinski's Sign, and Nuchal Rigidity in Adults with Suspected Meningitis. Clinical Infectious Diseases. 2002;35(1):46-52.

22. Makoo, Z., Ahadi, N., Hasani, A., Makoo, R., \& Mashrabi, O. Cerebrospinal Fluid Ferritin for Differentiation of Aseptic and Bacterial Meningitis in Adults. American Journal of Infectious Diseases. 2010;6(4):98-102.

23. Martin C, Burdon P, Bridger G, Gutierrez-Ramos J, Williams T, Rankin S. Chemokines Acting via CXCR2 and CXCR4 Control the Release of Neutrophils from the Bone Marrow and Their Return following Senescence. Immunity. 2003;19(4):583-593.

24. Abdelkader N, Mahmoud W, Saber S. Serum procalcitonin in Egyptian patients with acute meningitis and a negative direct cerebrospinal fluid examination. Journal of Infection and Public Health. 2014;7(2):106-113.

25. Sáez-Llorens X, McCracken G. Bacterial meningitis in children. The Lancet. 2003;361(9375):2139-2148.

26. Chow E, Troy S. The Differential Diagnosis of Hypoglycorrhachia in Adult Patients. The American Journal of the Medical Sciences. 2014;348(3):186-190.

27. Schwarz S, Bertram M, Schwab S, Andrassy K, Hacke W. Serum procalcitonin levels in bacterial and abacterial meningitis. Critical Care Medicine. 2000;28(6):1828-1832.

28. Nazir M, Wani W, Malik M, Mir M, Ashraf Y, Kawoosa $\mathrm{K}$ et al. Cerebrospinal fluid lactate: a differential biomarker for bacterial and viral meningitis in children. Jornal de Pediatria (Versão em Português). 2018;94(1):88-92. 
29. Buch K, Bodilsen J, Knudsen A, Larsen L, Helweg-Larsen J, Storgaard $M$ et al. Cerebrospinal fluid lactate as a marker to differentiate between community-acquired acute bacterial meningitis and aseptic meningitis/encephalitis in adults: a Danish prospective observational cohort study. Infectious Diseases. 2018;50(7):514-521.

30. Kleine T, Zwerenz P, Zöfel P, Shiratori K. New and old diagnostic markers of meningitis in cerebrospinal fluid (CSF). Brain Research Bulletin. 2003;61(3):287-297. 